\title{
RESEARCH PAPER \\ EMPIRICAL EXAMINATIONS OF CONFLICTS AND CONTRADICTIONS IN ARCHITECTURE, LAND AND SUBURBAN SPRAWL: THE CASE OF TAMALE, GHANA
}

\author{
R. A. Oppong and E. Yeboah \\ College of Architecture and Planning, KNUST, Kumasi \\ E-mail: rexfordoppong.cap@knust.edu.gh; assasie2003@yahoo.co.uk
}

\begin{abstract}
Tamale, like all the major cities in Ghana is confronted with a myriad of challenges. These challenges range from housing development without planning permission, sprawl and consequent suburban development. Based on a case study approach within the qualitative research methodology, a total of 738 adult population from four sectors in Tamale were sampled and interviewed to solicit their views on land, architecture, urban sprawl and suburban development in Tamale. This study in conclusion recommends an integrated approach to address architectural, land management and planning issues for the benefit of land and property owners as well as providing prospective developers access to land to enhance the economic and physical image of Tamale as an evolving metropolis.
\end{abstract}

Keywords: conflicts, contradictions, suburban sprawl, architecture, land, Tamale-Ghana.

\section{INTRODUCTION}

When the first census was conducted in the Gold Coast (now Ghana) in 1921, the total population was 2,298,000 (National Urban Policy, 2010). Out of this, 7.8 percent were classified as urban dwellers with the remaining 92.2 percent living in rural areas. The population of Ghana as at 2010 was 24, 658,823(Ghana Statistical Services [GSS], 2012) representing eleven-fold increase within eight decades. Within the same period, Ghana has moved from a predominantly rural country to an urban society with 51.5 percent of the population officially classified as urban dwellers (UN-DESA,
2011), making population growth and urbanisation phenomenal.

Land is a finite resource and therefore fairly fixed in its supply. As rural areas become urbanised and existing urban areas expand, there arises a corresponding increase in the demand for land especially for housing, industrial and commercial activities. Significantly, most of these land uses compete for the limited land. It is against this backdrop that urban management has gained attention at the national level (National Urban Policy, 2010) and the international front (UN Habitat, 2009). Owning to the 
diversity of needs of urban dwellers, an interdisciplinary approach has long been recommended as the most appropriate way of managing urbanisation (Urban Futures, 2000). The professions which are particularly central in the urban management discourse are architecture, land economy/real estate development as well as planning. Whereas architects are primarily preoccupied with designing and constructing buildings, land economists and planners are mainly concerned with ensuring the highest and best land use within the context of sustainable development. A synergistic relationship between architecture, planning and land management is therefore a prerequisite for adequately managing urbanisation.

Undoubtedly, land is a multifaceted aspect of urban development and land is an intrinsic part of virtually all aspects of urban life (Kivell, 1993). The prevailing land tenure systems therefore continue to shape urban forms in Ghana (Ubink and Quan, 2008). Reforming land tenure to meet the demands of urbanisation has therefore engaged the attention of various post independent governments. Indeed Adarkwa (2012), Gockling (2005) and Kasanga (1992) have argued that the checkered image of physical development and architecture of towns and cities in Ghana only reflect its political past. Presently, land sector problems are acute, particularly in urban and suburban areas where the growing population has increased socioeconomic activities and demand for land. Government interventions meant to address land and architectural problems seem worsening and suburban areas are becoming less secure as commercial transactions and housing development increase.

It appears extremely challenging for Ghana to address housing deficits due to low income levels of the Ghanaian working population, land tenure system, and relatively high cost of building materials. Private sector housing supply has not been favourable due to a high banking interest rate regime prevalent in Ghana and therefore the opportunity and capacity for in- come-earning Ghanaians to own houses through mortgaging remains unpopular if not non-existent. Housing provision is mainly through self help initiatives (Obeng-Odoom, 2008). This starts by acquiring a vacant land usually in the peri-urban interface and subsequently developing on incremental basis (Gambrah, 2002). This mode of housing has long been cited as a catalyst for urban sprawl (Farooq and Ahmad, 2008). The issue of urban sprawl is a challenge mirrored across almost all emerging economies such as Ghana. Though there is no evidence to show the extent of sprawl and suburban development in Ghana; experiences are almost invariably synonymous to Kellett's (2011) assertion that in Ghana suburban land and open spaces such as natural reserves meant for agrarian and social activities as well as "urban ecology" are sold for uncoordinated architectural development due to increase in population (Asiama, 2004).

The quest for responsive and sustainable (green) urban architecture and land management to control sprawling in Ghana is paramount but, it is seemingly complicated and elusive. Any move by successive Ghanaian governments to streamline land affairs is met with resistance, conflicts and deaths (refer to Asiama's (2004) account on Pakyi No. 2). Critics of sprawl and suburban developments assert that it is economically inefficient, socially inequitable, environmentally irresponsible and ugly (Bruegmann, 2005). However, Bruegmann (2005), Burchell et al. (2005), Kolb (2008) and Gillham (2007) reject every assumption about sprawl by taking a long view of urban development. They demonstrate that sprawl is inherent in a priori knowledge of human settlements and is neither recent nor particularly for one nation but as old as cities themselves, just as characteristic of ancient Rome and eighteenthcentury Paris as it is of Atlanta or Los Angeles.

Evidence alluding to the inextricable relationship between land and architecture abound (Njoh, 2007). However in Ghana, it has become customary for authors, commentators and pro- 
Land, architecture, urban sprawl and suburban development... 94

fessionals to isolate land from architecture in urban discourses (Asiama, 2004; ObengOdoom, 2008). This has resulted in a disconnection, a situation which has contributed to the growing conflicts and contradictions in search of efficient architecture and land management models to enhance economic developments. It is not uncommon to find sprawling ramshackle houses on one hand and abandoned low density housing projects on the other hand in various parts of urban and rural Ghana due to land litigations and conflicts in land use. The theoretical trends of land use management as well as sprawl and low density development and to a lesser extent architecture discussed throughout this introductory section help to better understand the various factors of sprawl, land use/ management and architecture in Ghana.

From empirical perspectives based on the peoples' perceptions, the questions this paper attempts to address are: What are the driving forces or reasons behind suburban sprawl in Tamale? Is sprawl perceived as beneficial? Who are the people behind sprawl? What are the effects of sprawl? What is the rationale behind refusal to redevelop poorly maintained old houses on prime urban land? Does architecture have a role to play in efficient use of land to ameliorate the effects of sprawl? This paper also speculates that suburban sprawl in Tamale is driven mainly by residents of Tamale due to lack of land in the urban core and for economic reasons and benefits.

\section{A NEXUS OF LAND, ARCHITECTURE AND KINSHIP IN TAMALE}

Land issues in Ghana have been a constant concern and reflected in the works of planners, land economists, anthropologists, sociologists and lawyers. Again, discussions and debate on land tenure systems in Ghana with diverse commentaries have been carried out by numerous authors and institutions. The common theme that runs through writings on land is the emphasis on religiosity of land in Ghana (Rattray, 1923; Eyre-Smith, 1940; Kasanga, 1988; Hooko, 2000; Kasanga and Kotey, 2001).
Traditional landownership dominates the private land sector with strong kinship orientation. Tenurial rights (allodial) or interest are vested in ethnic groups represented by chiefs and families/clans (Mahama, 2004; Manoukian, 1952; Duncan-Johnstone and Blair, 1932).

Tamale, the focus of this paper is widely and populated by 80.7 percent of the patrilineal Mole-Dagomba ethnic group. The MoleDagomba ethnic group has Islam as the dominant religion and polygamy is very popular. In the patrilineal descent system (agnatic descent), an individual is considered to belong to the same descent group as his or her father's kinship structure. The kinship system in northern Ghana manifests in most house structures which are characterized by circular building layouts. A typical compound house is normally composed of related individuals. In the rural areas, the traditional compound house has provided the basis for strong and extensive social relations. Compound houses form a chain of kinship relations on strong patrilineal lines.

Nevertheless, Tamale has seen exogenous influences on compound houses and architectural building forms over the years. The dynamics of social and economic development have caused many people to settle outside the urban historic core centres in recent times along non strict lines of kinship relations consistent with the communal lifestyle of pseudo-kinship relationships. There are groups and kin dispersal (Fortes, 1956). New neighbourhoods in Tamale seemingly consist of non-lineage members with the world view that every place is as good as one's hometown. The compound house concept which is considered the embodiment of the kinship lineage is gradually loosening in importance (Andersen et al. 2006). Most of the compound houses which served as architectural legacies with strong kinship ties are undergoing transformation into modern buildings or have become derelict and ran down as a result of neglect and a break down in kinship ties.

In spite of severe economic constraints, family 
members do not exercise the option of completely selling off or relinquishing their interest in land or property inherited from their ancestors (Adarkwah and Oppong, 2005). Danquah (1928) states elsewhere that, "an absolute sale of land is not simply a question of alienating reality; notoriously, it is a case of selling a spiritual heritage for a mess of pottage, a veritable betrayal of ancestral trust, an undoing of the hope of posterity". Danquah's (1928) assertion is still the reality and even though, that is gradually changing, there are all sorts of beliefs associated with compound or family houses (Grischow, 2008); rendering them 'untouchables'.

In most cases, compound or family houses are left to deteriorate on prime urban land normally apportioned with physical dimension of $30 \mathrm{~m} \mathrm{x}$ $30 \mathrm{~m}$. The traditional house forms of northern and southern Ghana are gradually disappearing. Most of the buildings in suburban areas of Tamale are single family houses containing two or three bedrooms with toilets and bathrooms, living, dining and study rooms as well as kitchen, store and garage. The houses are completely foreign in their forms and that prevent people from following traditional lifestyles as pertained in the traditional circular compound houses. The suburban houses do not appear to offer open and direct social intercourse to promote easy and free neighbourliness due to the construction of high security walls designed against burglary. Entry is provided through a metal gate, sometimes with a manned security house, quite unlike the traditional housing where the openness in design and layout of houses provide inherent security as well as kinship intercourses.

\section{STUDY AREA AND RESEARCH METH- ODS \\ Portrait of Tamale}

Tamale, the capital and medium-sized city of the Northern Region of Ghana and its suburban areas were selected for this study. The City of Tamale within the Guinea Savannah belt was deemed an excellent context for this research because it is experiencing suburban growth whilst the urban core is characterised by low density and run-down traditional houses on prime lands. Being at the centre of Ghana's agenda of infrastructural development, largely as a regional capital and service centre of the Northern Region of Ghana, the city attracts population from all over the northern region; migrants and immigrants in recent times. Tamale occupies the heart of a transportation network linking it to lesser towns and villages which surround it and complete the constellation of major towns and satellites typical of many dynamic cities (Fig.1).

Traditionally, Tamale is called Gulkpegu (part of Dagbon) headed by the Gulkpe- Naa (Chief). Tamale is highly respected by all Dagombas and all other ethnic groups in the Northern, Upper-East and Upper-West Regions of Ghana due to its geographical location and economic power. For instance, the late Ya-Na Yakubu Andani II started building a residence at Bayan waya (suburb) near the Kaladan Park in Tamale. Tamale is composed of various neighbourhoods or communities ruled locally by a total of 49 chiefs, some of whom are paramount or divisional chiefs. The population of the Tamale Metropolis is currently estimated to be 371,351 with an intercensal (2000-2010) growth rate of 2.5 percent. The growth rate of Tamale is closer to the national rate of 2.7 percent and the regional rate of 2.9 percent respectively (GSS 2012). The size of Tamale is approximately 922 kilometers square. The urban population of Tamale stood at $67.1 \%$ as at 2005 and that made the Metropolis the only local government area in the northern region which is predominantly urban (GSS, 2005). The GSS (2005) gave a 'population density of 318.6 persons per square kilometer for the Tamale Metropolis which is about 12 times higher than the regional average density of 25.9 persons per square kilometer', a situation that partly helps to explain the high rate of urban sprawl in the area. Economic activities revolve around farming in the suburban areas and commerce in and around the Central Business District (CBD) of 
Land, architecture, urban sprawl and suburban development... 96

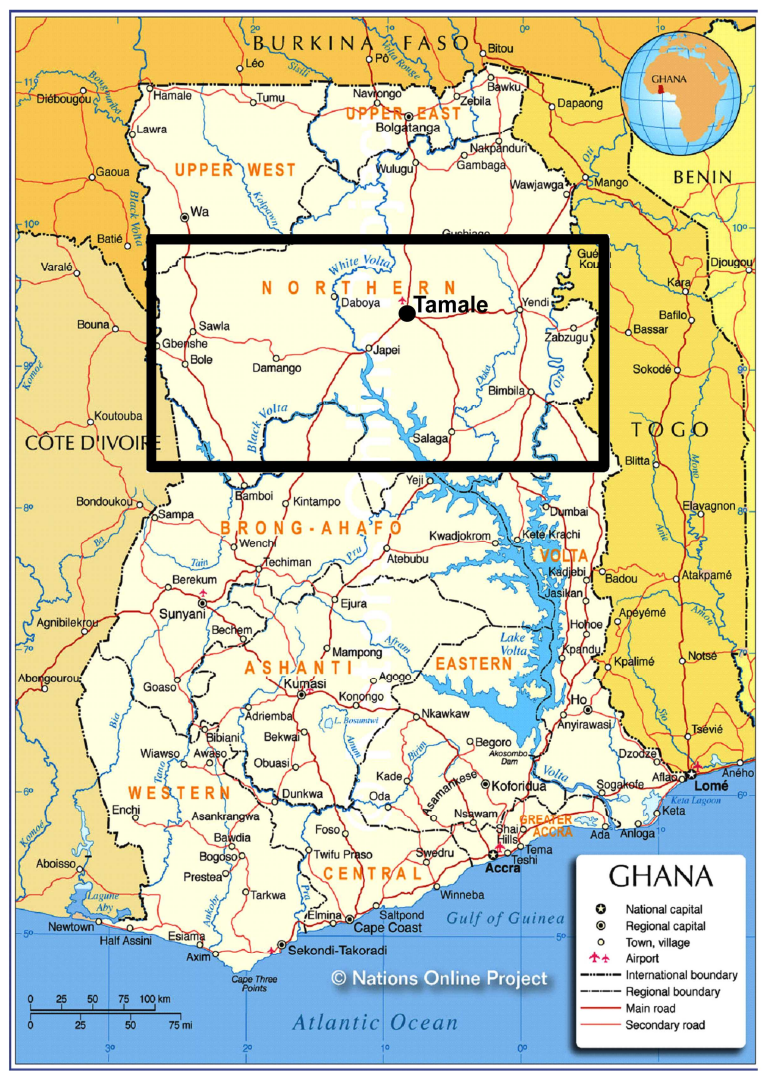

Fig.1: Map of Ghana with Tamale and its surrounding towns/villages

Adapted from: http://www.google.co.uk/imgres?imgurl=http://www.nationsonline.org/maps/ghana_map.jpg\&imgrefurl

Tamale. The low -income areas are contiguous to the central business district. Middle income areas are scattered in the city. The eastern part of Tamale is dominated by high income housing enclaves of which are found on the town's periphery to the north and west.

\section{METHODS AND APPROACHES}

Appropriate research techniques and strategies were adopted to better understand peoples' perceptions, experiences and attitudes on the apparent contradiction of suburban sprawl amidst poorly managed open spaces as well as virtually vacant and ram-shackled low-density buildings occupying prime lands in the urban core of Tamale. Powe and Hart (2011) have argued that, 'the community and its interpretations of social issues cannot be ignored when testing out perceptions to guide policy-making and implementation'. Therefore, the use of a case study as a research technique for an indepth understanding and better appreciation of the valued aspects of peoples' experiences and attitudes is useful (Aung-Thwin, 2008). For instance, it is questioned elsewhere that "how can economists claim they know more about the people they study than the people themselves?"(Obeng-Odoom, 2010). Since case study methodology is of utmost importance in architectural, land administration and planning related researches (Walters and Brown, 2004), it was used in this research. 
97

Oppong and Yeboah

Selected case study areas

Four sectors of Tamale were chosen for the study (Table 1). The first is Tamale Central which comprises of Bupiela, Nyani-Fong, Sabon-Gida, Dabokpa, Tutingli, Dohinayili, Changli, Gumbihini, Choggo-Manayili, Ridge, Kalpohini, Sakasaka, Gumani, Kukuo, Aboabo, Moshie zongo, Tishigu, Nyohini and Sanerigu. The other three active suburban areas of Tamale chosen are NORRIP/Kanvilli Village, Lamashegu/Lamakara Village and Jekeriyili/ Vitin Village.

\section{Field Surveys}

Field surveys were undertaken from June 2008 to November 2009. Guided by the ethical consideration of gaining access (Bell, 1991) we announced our presence in Tamale to the Tamale Metropolitan Assembly (TMA) through the Metropolitan Coordinating Director. Mixed methodological approach was used to gather information on perceptions, land tenure system and suburban sprawls as well as the extent to which people want to see Tamale develop into a world class city to attract tourism for economic prosperity. A sixteen-day pilot ethnographic interview sessions with residents was undertaken from $15^{\text {th }}-31^{\text {st }}$ June, 2008 and that helped to generate responses relating to the degree of accuracy of the questions about suburban sprawl.

A total of 738 adult population of Tamale (aged 18 years and over) were interviewed in the four sectors. The number 738 resulted from exploratory and nonprobabilistic (convenience and purposive) sampling techniques (refer to Basile et al., 2010; Ahmed et al., 2007; Wang, 2002). Initial views on architectural, land use and planning issues were sampled (as part of the 738) from city administrators, Town and Country Planning Officials, multinational companies (e.g. banks), traditional rulers and opinion leaders and individuals. Themes drawn from the initial views informed our semi-structured questionnaire. Participants/Respondents were were recruited with the help of the Tamale Metropolitan Assembly Assembly (TMA),

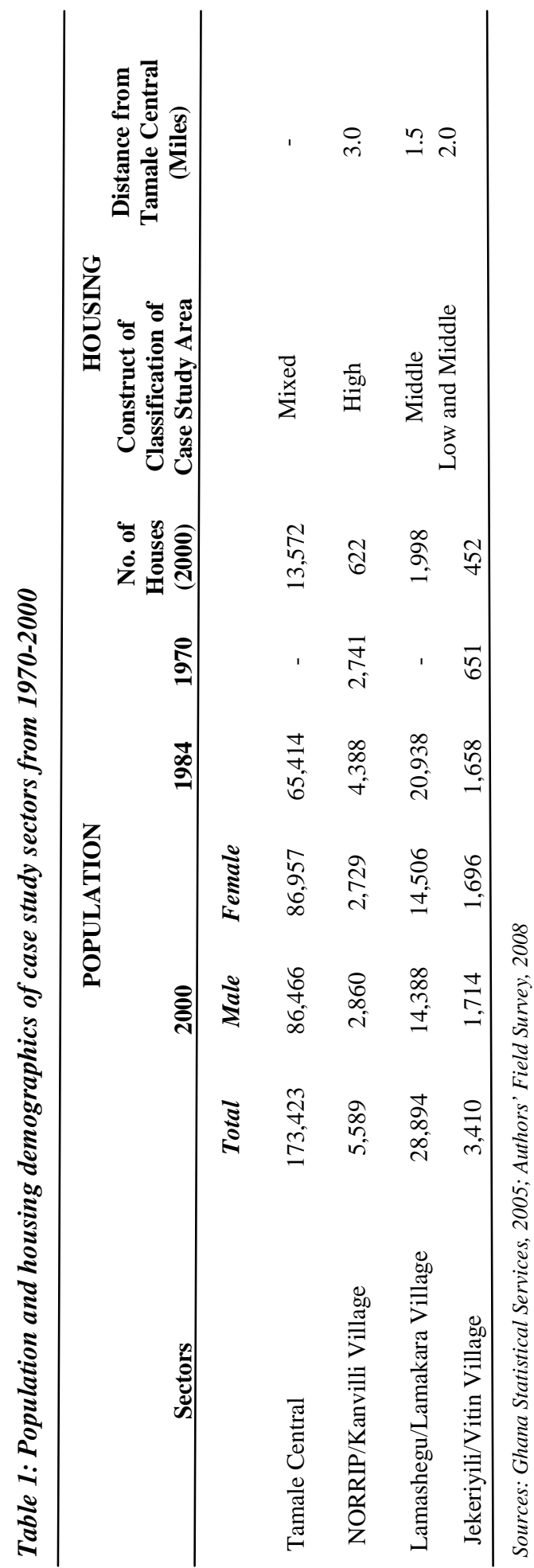

Journal of Science and Technology @ KNUST April 2013 
Land, architecture, urban sprawl and suburban development... 98

traditional and opinion leaders, and Unit Committee members of TMA. A 'computerassisted focus group discussion and interview (CAFGDI)' was applied where power-point presentation (PPP) of aerial view of the CBD and sections of suburban areas of Tamale were made to research participants before interview and discussion sessions. That approach enabled the research participants to have vivid understanding of the extent of suburban sprawl in Tamale. Thirty four participants made up of the three from TMA, 12 traditional and opinion leaders, 12 Unit Committee members, two teachers, and one town planning officer as well as four building industry professionals, took part in our one-day CAFGDI. The involvement of local people opened doors for us to meet other participants whose views became credible to this research.

\section{Sample Size and Data Analysis}

The data analysis techniques were inductive on one hand and statistical on the other: narratives and responses to open-ended questions within the semi-structured questionnaires and focus groups and ethnographic interviews were inductively analysed. The data was stratified, for example, by area of residence, gender, age, occupation and work status. Statistical Package for Social Scientists (SPSS) was used to generate descriptive statistics for analysis as reflected in the findings and discussions section of this paper.

\section{SUMMARY AND DISCUSSIONS OF MAIN FINDINGS}

The main findings that emerged from the analysis of the survey data are presented to respond to the questions posed earlier in the introductory section. The findings, however, have been supplemented with some descriptive statistics from the larger survey. The responses were used to give some indication of the general perception of urban land and architectural development issues vis-à-vis suburban sprawl in Tamale. The responses reasonably varied but the central point appeared to be that suburban sprawl in Tamale is beneficial. However, in the
Tamale study, respondents' views on sprawl were mixed (Table 2): whilst almost 30 percent of those interviewed perceived sprawl as good because it helps cities to grow, 26 percent considered sprawl to be detrimental to food production because it destroys farmlands and people especially farmers become landless. Again, about 30 percent did not have any idea about suburban sprawl; which could be an indication that they did not understand urban sprawl.

Notably, the issues of landlessness is not new in northern Ghana as a whole (Kasanga and Kotey, 2001) and across the world (Athanasiou, 1998). A little over seven percent (7.2\%) of the respondents thought sprawl "helps personal preference for building"; whilst 27 percent did not have an idea about sprawl. Notwithstanding the negative concerns some respondents have about suburban sprawl, the data analysis revealed an apparent contradiction where about 46 percent of the respondents preferred to live at Kanavilli - a suburban area of about 3 miles from Tamale Central as compared to eight percent who preferred Tamale Central. Respondents also seemed to reject Lamakara/ Lamashegu due to their proximity ( 1.5 miles) to Tamale Central (Table 3).

Respondents from the four sectors offered a mixture of reasons for suburban preference as in Table 4. Slightly over 28.2 percent preferred suburban areas to offer good lifestyle for their children and about 25 percent for modern house and facilities such as schools, banks, hospital and airports. Interestingly, about 13.0 percent of the respondents preferred suburban areas for economic benefits.

Supporting evidences from our ethnographic interactions revealed that people engaged in land speculation activities for economic benefits as a bank official's narrative shows that:

"Lands in the centre of Tamale are shrouded in multiple-ownership. We tried to purchase an old building in the centre to demolish for a new bank building facility but that was more complex. One building we 
approached had almost 30 people as owners. Some agreed to sell but many others did not. Obviously developing a bank in the central business area is the best but our Bank preferred to come to Kanavilli (suburban area) because the chief of the village was happy to have a bank in his village and together with his elders sold this land for the bank to develop and interestingly people come from the centre to do business with the

Table 2: Respondents' views on suburban sprawl in Tamale

\begin{tabular}{lcc}
\hline Preferred Areas & Frequency & Percentage \\
\hline Tamale Central & 59 & 8.0 \\
Lamakara/Lamashegu & 78 & 10.6 \\
Vittin Village & 192 & 26.0 \\
Kanavilli village & 337 & 45.7 \\
Other (preferred all four areas) & 64 & 8.7 \\
Missing & 8 & 1.0 \\
Total & $\mathbf{7 3 8}$ & $\mathbf{1 0 0 . 0}$ \\
\hline
\end{tabular}

Table 3: Most preferred areas in Tamale

\begin{tabular}{lcc}
\hline Preferred Areas & Frequency & Percentage \\
\hline Tamale Central & 59 & 8.0 \\
Lamakara/Lamashegu & 78 & 10.6 \\
Vittin village & 192 & 26.0 \\
Kanavilli village & 337 & 45.7 \\
Other ( preferred all four areas) & 64 & 8.7 \\
Missing & 8 & 1.0 \\
Total & $\mathbf{7 3 8}$ & $\mathbf{1 0 0 . 0}$ \\
\hline \hline
\end{tabular}

Table 4: Reasons for choosing to live in suburban areas in Tamale

\begin{tabular}{lcc}
\hline Reasons for Suburban living & Frequency & Percentage \\
\hline Economic benefits & 95 & 12.9 \\
Availability of modern houses/facilities (banks, Hospitals & & \\
and schools, Airport) & 181 & 24.5 \\
Quietness & 58 & 7.9 \\
Breaking away from extended family system & 51 & 6.9 \\
Good lifestyle for children & 208 & 28.2 \\
Availability/litigation-free lands & 70 & 9.5 \\
Modernity and status symbol & 42 & 5.7 \\
Neat surroundings and good roads & 33 & 4.5 \\
Total & $\mathbf{7 3 8}$ & $\mathbf{1 0 0 . 0}$ \\
\hline
\end{tabular}


Land, architecture, urban sprawl and suburban development... 100

bank.”

The study found that access to land in the centre of Tamale was complex. The inheritance system which is woven around a complex web of property rights has long been cited as increasing the transaction cost of land acquisition especially in the urban core (Hammond et al, 2006). This situation eventually helps to push prospective developers to the urban fringe. There is therefore sprawling whereas lands in the inner city remain vastly vacant thereby reinforcing the contradictions. Subjective actions of local people embedded in the cultural milieu regulate local perceptions that land belonging to families cannot be sold. In some parts of Tamale, the traditional land owners are chiefs whilst in other parts they are families. Land acquisitions and documentations therefore require the consent of the paramount or divisional chiefs and family heads to be valid. Characteristic of the conflicts and contradiction embedded in land access, rights and ownership was this respondent's statement below:

"My late father bequeathed a house to his 21 children from seven different women as wives. The house is very old and does not have facilities such as toilets. There is only one bathroom shared by all the people in the house. Nobody is prepared to help in redeveloping the house into a modern one and I cannot use my money to redevelop the whole house, so I prefer to build my personal one elsewhere in the outskirts like Vittin, Kanavilli, Dogtse etc".

Another respondent preferred suburban areas to the centre of the city of Tamale because;

"Land and old buildings in the city have many owners and you cannot just touch them. Multiple-building-ownership is a culture and really difficult to change. In fact I doubt if it can be changed at all since it is really embedded in our culture. The outskirts are far better because the city is very noisy and there are bad habits which do not help child upbringing. I prefer to live outside the city centre. If you have a car, it is easy to come to the city centre; you can even walk or use bicycle or motor bike”.

Apart from the foregoing, the survey data showed interestingly contrasting figures. For instance, about 32 percent of the respondents indicated that multiple-building-ownership accounted for the non-redevelopment of old and dilapidated buildings occupying prime lands in Tamale Central (Table 5). In addition to the multiple-building-ownership, about 31 percent of the respondents gave reasons such as lack of cooperation amongst family members, superstition and religious beliefs as well as difficulties in acquiring building permits accounted for lack of redevelopment in Tamale Central. Instead, developers look for land in suburban areas where land acquisition appears to be easy. Responses to stop suburban sprawl in Tamale was mixed. About 23.3 percent of respondents suggested that city authorities take control of land issues whilst 26 percent were of the view that re-planning and re-zoning of the CBD lands in Tamale can stop sprawl and bring sanity into the land management and architectural practices in Tamale as a whole (Tables 6).

\section{CONCLUSIONS AND RECOMMENDA- TIONS}

This article has endeavoured to show that there are conflicts and contradictions in land tenure and management as well as architectural practices and their resultant effect on suburban sprawl in Tamale. Again, this article reveals that land management in the centre of Tamale is seemingly problematic due to opposition by local residents who act as barriers to the redevelopment of derelict buildings on prime lands. Authors have noted that a combination of several factors including: multi ownership, lack of funds, difficulty in obtaining building permit, superstitious and religious beliefs as well as lack of cooperation amongst family members due to complex inheritance culture have brought about the apparent conflicts and contradictions in architectural practices and land management system in Tamale Central with consequent effect of suburban sprawl. 
Table 5: Main reasons for non redevelopment of land/Old buildings in Tamale Central

\begin{tabular}{lll}
\hline Reasons for non redevelopment in Tamale Central & Frequency & Percentage \\
\hline Lack of funds & 44 & 6.0 \\
Family property/inheritance & 33 & 4.5 \\
Difficulties in building permit acquisition & 56 & 7.6 \\
Superstitious/religious beliefs & 52 & 7.0 \\
Lack cooperation amongst family members & 90 & 12.2 \\
Multi ownership & 234 & 31.7 \\
Others (combination of all the above) & 228 & 30.9 \\
Missing/Not relevant & 1 & .1 \\
Total & $\mathbf{7 3 8}$ & $\mathbf{1 0 0 . 0}$ \\
\hline
\end{tabular}

Table 6: Stopping suburban sprawl

\begin{tabular}{lcc}
\hline How to stop suburban sprawl & Frequency & Percentage \\
\hline Building high in CBD & 62 & 8.4 \\
Availability of CBD land & 81 & 11.0 \\
Control by City Authorities & 172 & 23.3 \\
Re-planning and re-zoning of & & \\
Tamale Central lands & 195 & 26.4 \\
Not sure & 49 & 6.6 \\
Not Relevant & 173 & 23.4 \\
Missing & 6 & .8 \\
Total & $\mathbf{7 3 8}$ & $\mathbf{1 0 0 . 0}$ \\
\hline
\end{tabular}

Notably, the descriptive frequencies of data revealed 'modernity and good lifestyle for children' whilst the qualitative data of respondents highlighted economic reason to a considerable extent as the main drivers of suburban living and development. Over 23 percent of respondents suggested that city authorities take control of land issues whilst 26.4 percent were of the view that re-planning and re-zoning of CBD lands in Tamale can stop sprawl and bring sanity into the land management and architectural practices in Tamale as a whole.
Following that, this article recommends that if there is a single policy guideline for architectural, planning and land management in Tamale, it is crucially important that city authorities engage land owners in a consultative dialogue to educate the people to map out interventions that can free lands and buildings (especially in Tamale Central) from cultural encumbrances such as family inheritance. Again, the authors find it expedient to re-echo the assertion made elsewhere by Kasanga (1992) that to deal with land management issues in northern Ghana, there is the need to 
"address emergent socio-cultural and economic problems within a context of integrated land management". Kasanga (1992) further suggested "among other things, the application and/or "marriage" of new management practices, professional expertise, techniques, and resources, to customary, social, and institutional arrangements at appropriate levels to optimise available human, land, and financial resources". This paper concludes with the view that such interventions/recommendations stand to benefit individual land and property owners as well as providing prospective developers access to land to enhance the economic and physical image of Tamale as an evolving metropolis.

\section{REFERENCES}

Adarkwa, K. K. (2012). "The Changing face of Ghanaian towns", African Review of Economics and Finance, 4 (1): 1 - 29.

Adarkwa, K. K. and Oppong, R. A. (2005). "Gentrification, Use Conversion and Traditional architecture in Kumasi's Central Business District - Case Study of Odum Precinct", Journal of Science and Technology, Kumasi - Ghana, 25 (2): 80 - 90.

Ahmed, Z. U., Ghingold, M. and Dahari, Z. (2007). "Malaysian shopping mall behavior: an exploratory study", Asia Pacific Journal of Marketing and Logistics, 19 (4):331 - 348.

Andersen, J. E., Andreasen, J. and Tipple, G. (2006). "The demise of compound house: consequences for the low income population of Kumasi, Ghana", RICS Research Paper, 6 (8):1-43.

Asiama, S. O. (2004). "Current Changes in customary/traditional land delivery systems in sub Saharan African cities, case study of Kumasi", Paper present at International Workshop on Land for Housing in African Cities. P and DM, Johannesburg, South Africa.
Athanasiou, T. (1998). Divided Planet- The Ecology of the Rich and Poor, The University of Georgia Press, Athens and London.

Aung-Thwin, M. (2008). "Mranma Pran: When context encounters notion", Journal of Southeast Asian Studies, 39 (2):212-214.

Basile, G., Addeo, F. and Spagnuolo, R. (2010). "Local products as a key for economic development driven by tourism: a case study research in Irpinia", International Journal of Management Cases, Special Issue: CIRCLE Conference, (13):387399.

Bell, J. (1991). Doing Your Research Project, Milton Keynes. Open University Press.

Bruegmann, R. (2005). Sprawl: a compact history, University of Chicago Press, Chicago; London.

Burchell, R., Downs, A. and Mukherji, S. (2005). Sprawl costs: economic impacts of unchecked development, Island Press, Covelo, CA, USA.

Danquah J. B. (1928). Akan Laws and Customs and the Akim Abuakwa Constitution, Oxford University Press, Oxford.

Duncan-Johnstone, A. and Blair, H. (1932). Enquiry into the Constitution and Organisation of the People of Dagbon Kingdom, Ghana Publishing Corporation, AccraGhana.

Eyre-Smith, S. J. (1940). Government Sociologists' Report on Ada and the Volta side, Republic of Ghana.

Farooq, S. and Ahmad, S (2008). "Urban Sprawl Development Around Aligarh City:Aided by Satellite Remote Sensing and GIS", Journal of the Indian Society of Remote Sensing , 36 (1):77-88. 
Fortes, M. (1956). "Kinship and Marriage Among the Ashanti" In: African Systems of Kinship and Marriage (A.R RadcliffeBrown, \& Daryll Forde, eds.), Oxford University Press, London.

Gambrah, A. (2002). Improving Land Transfer Procedures in Ghana, Journal of Science and Technology, Kumasi, 22 (1, 2\&3): 22-33.

Ghana Statistical Service (GSS), (2005). "2000 Population and Housing Census: Analysis of District Data and Implications for Planning", UNFPA funded project (GHA/01/P07), Accra.

Ghana Statistical Service (GSS), (2012). “2010 Population and Housing Census (PHC) Final Results", Accra, www.statsghana.gov.gh /2010phc,[accessed 20/04/2013].

Gillham, O. (2007). The urban design reader, Michael Larice and Elizabeth Macdonald (eds.), Routledge, London.

Gockling, R. S. (2005). The history of Ghana, Westport, Connecticut \& London: Greenwood Press.

Grischow, J. D. (2008). "Rural 'Community', Chiefs and Social Capital: The Case of Southern Ghana", Journal of Agrarian Change, 8 (1):64-93.

Hooko, D. (2000). Housing Development and Traditional Landownership in Tamale, Ghana, Unpublished PhD Thesis, University of Aberdeen.

Kasanga, K. and Kotey, N. A. (2001). "Land Management in Ghana: Building on Tradition and Modernity", International Institute for Environment and Development, London, pp.17-18

Kasanga, R. K. (1988). Land Tenure and the Development Dialogue: The Myth Concerning Communal Landholding in Ghana, Cambridge: Granta Editions Ltd.
Kasanga, R. K. (1992). “Agricultural land Administration and Social Differentiation: A Case Study of the Tono, Vea, and Fumbisi Belts of North-Eastern Ghana", .A paper presented to the Project on African Agriculture of the Joint Committee on African Studies Social Sciences Research Council/ American Council of Learned Societies.

Kellett, J. (2011). “The Australian quarter acre block: the death of a dream?" Town Planning Review, 82 (3):263-264.

Kivell, P. (1993). Land and the City; Patterns and processes of urban change, Routledge, London and New York.

Kolb, D. (2008). Sprawling places, University of Georgia Press, Athens; London.

Mahama, I. (2004). History and Traditions of Dagbon, GILLBT Printing Press, Tamale Ghana.

Manaoukian, M. (1952). Tribes in of Northern Territories of the Gold Coast, International African Institute, London.

National Urban Policy (2010). Ministry of Local Government and Rural Development, Accra.

Njoh, A. J. (2007). "Ideology and public health elements of human settlement policies in sub -Saharan Africa", Cities, 26 (1): 9-18.

Obeng-Odoom, F. (2008). "Has the Habitat for Humanity Housing Scheme Achieved its Goals? A Ghanaian Case Study", Journal of Housing and the Built Environment, 23(4):67 -84 .

Obeng-Odoom, F. (2010). "Jim Stanford, Economics for Everyone: A Short Guide to the Economics of Capitalism", African Review of-Economics and Finance, 2 (1): 1-4. 
land, architecture, urban sprawl and suburban development... 104

Powe, N. A. and Hart, T. (2011). "Housing development and small town residential desirability - Valued aspects, resident attitudes and growth management", Town Planning Review, 82 (3):317-340.

Rattray, R. S. (1923). Ashanti Law and Constitution, Ghana Publishing Corporation, AccraGhana.

Ubink, J. M. and Quan, J. F. (2008). "How to combine tradition and modernity? Regulating customary land management in Ghana", Land Use Policy, 25:198-213.

UN-DESA (2011). World Urbanization Prospects: The 2007 Revision of Population Database, Population Division, New York, http://esa.un.org/unup/ [assessed, 2/1/11].

UN-Habitat (2009). Ghana Urban Profile, UNHabitat, Nairobi.

Urban Future (2000). Global Conference on the Urban Future - URBAN 21: "Berlin Declaration on the Urban Future", Berlin Germany, 4- 6, July 2000.

Walters, D. and Brown, L. L. (2004). Design first: design-based planning for communities, Architectural Press, Oxford.

Wang, D. (2003). "A Critical Evaluation of Architectural Research in Light of Social Science Methodological Frameworks", Journal of Architectural Education, 56 (4): 5056. 